\title{
Use of Natural Coagulants for Removal of COD, Oil and Turbidity from Produced Waters in the Petroleum Industry
}

\section{Khader $\mathrm{EH}^{1^{*}}$, Mohammed $\mathrm{TH}^{1}{ }^{1}$ and Mirghaffari $\mathbf{N}^{2}$}

${ }^{1}$ Department of Chemical Engineering, University of Technology, Iraq

${ }^{2}$ Department of Natural Resources Engineering, Isfahan University of Technology, Iran

\begin{abstract}
The biggest amount of wastewater that produced from industry of petroleum is produced water, it contains suspended and dissolved solids, residual hydrocarbons, numerous organic species and heavy metals. It is very important to remove the organic pollutant compounds from the contaminated water before discharge into any natural water. This paper studies the effect of dose of natural coagulants, $\mathrm{pH}$ of produced water, and oil concentration on the removal of turbidity, COD and Oil from oilfield produced waters. The efficiency of turbidity, oil and COD removal was studied via three different natural coagulants (Cicer arietinum seed, eggplant seed and radish seed) used to decrease the turbidity and organic pollutants of produced water. The experiments of the jar test showed that Cicer arietinum seed at dose $1.5 \mathrm{mg} / \mathrm{L}$ and the best $\mathrm{pH}$ and oil concentration can remove $95.2 \%$ of chemical oxygen demand (COD), $83.8 \%$ oil content and $98.89 \%$ of turbidity. Also, the eggplant seed at optimum condition removed COD, turbidity, and oil content by $92.18 \%, 99.42 \%$, and $81.8 \%$, respectively from the produced water. Moreover, when radish seed was used, the removal of oil content, COD and turbidity will reach to $88.2 \%, 93.48 \%$, and $98.78 \%$, respectively.
\end{abstract}

Keywords: Coagulation; Flocculation; Natural coagulants; Turbidity; Oil; COD; Removal

\section{Introduction}

The industry of gas and oil deals with a huge amount of wastewater as a by-product to explore the gas and oil. This a massive quantity of wastewater represents a produced water and it increases when the operation time is well, and approximately that increase can reaches to $80 \%$ [1]. Due to discharge of produced water, the surface, soil and underground water may become very pollutant. The wastewater that produced from industry of Petroleum contains compounds: Inorganic and organic [2].

Colloid particles can be removed from wastewater by utilizing several traditional and advanced technologies, such as coagulation, flocculation, adsorption, ion exchange, flotation, membrane, precipitation, solvent extraction, biological, filtration and electrolytic methods [3]. Coagulation and flocculation treatment is among the methods available for water treatment, it is a simple, reliable, low cost and low energy consuming process that is commonly practiced [4]. It is an efficient method for treatment of water pollutant, and was used extensively for the treatment of different types of wastewaters such, as oily wastewater, pulp mill wastewater, sanitary landfill leachates, palm oil mill effluent, textile wastewater and others [5-8] because it did not require complex machineries; as well in the operation of process, no needs to consumption of energy, therefore we get the coagulant effective. It is an effective process to remove the colloid, soluble and suspended particles and also remove the other kinds of pollutants, such as organic compounds, color, micro pollutants, fat and oils during the aggregation that produced from macro and micro particulates into size of bigger ones followed by sedimentation [4].

In coagulation method, small particles are formed into larger aggregates (flocs). Dissolved organics matter will be adsorbed by these flocs. Larger particles are easier to remove by filtration or sedimentation. This process will reduce the dissolved organics matter and turbidity in liquids [9]. In general, there is a special definition for each of the term "coagulation and flocculation". Nevertheless, it was acceptable that referring for both processes as coagulation process in treatment of wastewater [10].
Coagulation includes the following stages:

(a) Coagulant forming;

(b) Particles destabilization; and

(c) Particles aggregation [11].

By adsorption, the particles and flocs have been aggregated by the natural coagulants and then followed by charge neutralization or bringing of particles. There are four mechanisms for coagulation to occur in the aggregation of particulates: (1) double layer compression; (2) sweep flocculation; (3) adsorption and charge neutralization; and (4) adsorption and inter particle bringing [9]. Therefore, coagulation is the process of destabilizing the colloids, suspended substances and other organic matter by adding coagulants to the liquids and allowing them to be converted into a bigger form that is easier to remove later. Different mechanisms, such as neutralization of charge, adsorption, and sweep flocculation can be responsible for the removal of organics particles and compounds depending on the concentration of coagulant and properties of water $[12,13]$.

Aluminium and iron salts are the most commonly coagulants used to the treatment of wastewater [14]. However, aluminium could cause different types of bad effects on the health of human, e.g. memory loss, intestinal constipation, abdomen colic, spasms, difficultly of learn and loss of energy when utilized as a coagulant in the treatment of wastewater. Therefore, at present, there is a great interest in the improving and implementing of natural coagulant in pollutant water treatment [15]. The plants, animals and minerals are sources of natural

"Corresponding author: Khader EH, Department of Chemical Engineering, University of Technology, Iraq Tel: +964 790144 9044; E-mail: eman.hashim1990@gmail.com

Received July 08, 2018; Accepted July 16, 2018; Published July 25, 2018

Citation: Khader EH, Mohammed THJ, Mirghaffari N (2018) Use of Natura Coagulants for Removal of COD, Oil and Turbidity from Produced Waters in the Petroleum Industry. J Pet Environ Biotechnol 9: 374. doi: 10.4172/21577463.1000374

Copyright: (c) 2018 Khader EH, et al. This is an open-access article distributed under the terms of the Creative Commons Attribution License, which permits unrestricted use, distribution, and reproduction in any medium, provided the original author and source are credited. 
coagulants. Natural coagulants that got from the plants are more common due to their suitability for large production and practicability for it. Natural coagulants are nontoxic, renewable, produce lower sludge, biodegradable and relatively cost effective $[9,16,17]$. Moreover, natural coagulants have a wide range of effective dosage and do not change the value of $\mathrm{pH}$ for treated water $[9,18]$. Therefore, the aim of present work is to study the use of natural coagulants in low concentration, such as Cicer arietinum seed, eggplant seed and radish seed which are locally available from vegetables for treatment the produced water. There are no any conducted experiments by the researchers for the treatment of produced water with using the seeds of eggplant and radishes, but some of them have used the Cicer arietinum at high concentration up to 50 $\mathrm{mg} / \mathrm{l}$, where there is no researcher has used low concentration up to 1.5 $\mathrm{mg} / \mathrm{L}$ of the Cicer arietinum seed alone.

\section{Research Methodology}

\section{Materials}

In this research three various natural coagulants were utilized; Cicer arietinum seed, Eggplant seed and Radish seeds. All the coagulants used were provided by the local market.

Synthetic wastewater preparation: To prepare the synthetic produced water, some of chemical materials were added, such as clay materials, crude oil and salt to adjust properties of the produced water that treated in this research. The value of turbidity and oil of the synthetic water was set to become equal to the values of oil, turbidity and salt in the natural produced water. The clay materials and crude oil were added to the distilled water. The suspension was stirred for about $15 \mathrm{~min}$ at $2700 \mathrm{rpm}$ to get a uniform diffusion of oil drops and clay particles.

Natural coagulants preparation: The seeds of radish and eggplant were collected and then dried naturally by sunlight. By using domestic blender, the dried seeds were ground to fine powder and then this powder was sieved through $600 \mu \mathrm{m}$ sieve $[19,20]$. The size of granules powder should be less than $600 \mu \mathrm{m}$ approximately to realize the solubility of active components in the seeds. Distilled water was added to the powder seed to get $1 \%$ suspension of it, and then shake vigorously for $45 \mathrm{~min}$ by using a stirrer to enhance the water for extracting the proteins of coagulant, and then passes through the paper of filtration. This filtrated solution was used as dose of coagulant in the experiments. To avoid any effect, such as changing in viscosity, coagulation activity and $\mathrm{pH}$ that occur, the solution should be papered daily and kept in refrigerator. Solution must be shaking well before using it.

\section{Methods}

The experimental methods that were used in the coagulation/ flocculation treatment for wastewater were carried out by using jar test, which is most commonly. Samples of produced water that was used in the experiments was synthetic wastewater, the properties of the samples are shown in Table 1. Jar test was used to coagulate the samples of produced water by adding some coagulants in the experiment. All the experiments of coagulation - flocculation treatment were performed at the ambient temperature. The sample should be mixed well before using of the jar test and after that, the samples must be measured for oil, COD and turbidity to represent the initial concentration. 1liter of the produced water was put in beakers, then mixed at a high speed reaching to $150 \mathrm{rpm}$ for $1 \mathrm{~min}$ by using a stirrer, and then mixed slowly at a speed of $50 \mathrm{rpm}$ for $20 \mathrm{~min}$, and finally the sample was left to settle for $15 \mathrm{~min}$. After settling the sample, a volume of liquor supernatant was pulled at a distance of $5 \mathrm{~cm}$ from the surface of the sample for conducting the analysis required. Coagulants of varying concentrations (0.5-3) ppm were added in the beakers to determine the best dosage based on the minimum concentration of pollutants. To determine the best value of $\mathrm{pH}$, the experiments were carried out at the range of $\mathrm{pH}$ (2-11). Also, different concentrations of oil (50-1000) ppm were tested to find the best concentration of oil.

\section{Results and Discussion}

\section{Determination of optimum doses of coagulants}

Optimum dose for turbidity removal: Figure 1 shows the required optimum dose for various natural coagulants for reduction of turbidity. The removal efficiency of turbidity increases with increasing dose of natural coagulants until reaching the best removal at optimum dosage. The optimum dose for different coagulants in terms of turbidity removal is $1.5 \mathrm{mg} / \mathrm{L}$ for Cicer arietinum seed, $2 \mathrm{mg} / \mathrm{L}$ for eggplant and radish seed, and then the removal efficiency of turbidity decreased due to the overdose which caused restabilization of particle colloid. The performance of turbidity removal (98.68\%) was high when using eggplant seed compared to other natural coagulants and approximately the same for radish seed and Cicer arietinum seed at optimum dose.

Optimum dose for oil content removal: Figure 2 indicates the impact of dosage of natural coagulants on the efficiency removal of oil. It is clear that the oil content decreases with increasing dose of natural coagulants until reaching the optimum dose. Furthermore, increasing the doses causes an increase in the oil content and a reduction in the removal efficiency, the overdose results destabilization, which leads to a weak attraction between the oil droplets and then causes a reduction in the settling velocity of particles according to the Stock law, thus the removal decreasing? The optimal dose of $(1.5 \mathrm{mg} / \mathrm{L})$ for all coagulants has a significant effect on the removal efficiency of oil it reached the best removal (86.9\%) and residual oil (13.1 $\mathrm{mg} / \mathrm{L})$ by using radish seed.

Optimum dose for COD removal: The removal efficiency of COD by adding natural coagulants is shown in Figure 3. This figure reveals that the removal of COD increases with increasing the natural coagulants dose until the $\mathrm{R} \%$ reaches the maximum value and then decreases. The performance of process treatment decreased the result for re-stabilization of colloids in wastewater that caused by the coagulant overdose. In addition, overdosing of coagulant would increase the formation of sludge overly; increase the chemicals and residuals management costs. The optimum dose could not neutralize the colloidal due to the quantity of coagulant that was not enough for this purpose. Cicer arietinum seed was the best in removal of COD and gave the ratio of removal reached up to $(94.73 \%)$ and residual (132 $\mathrm{mg} / \mathrm{L}$ ) at the optimum dose $1.5 \mathrm{mg} / \mathrm{L}$.

\section{Determination of optimum $\mathrm{pH}$}

Another group of jar tests were carried out to evaluate the impact of $\mathrm{pH}$ on the efficiency removal of turbidity, oil and COD. Study the effect of $\mathrm{pH}$ on the effective process of coagulation is necessary because the solubility of particle and matters rely on the $\mathrm{pH}$ value of water Figures 4, 5 and 6 depict the removal of turbidity, COD and Oil at different $\mathrm{pH}$ values (2-11). According to these figures, it can be seen that the removal efficiency without prior adjustment of $\mathrm{pH}$ (7) was at the highest for all types of natural coagulants. Coagulation activity of natural coagulants in produced water becomes high at $\mathrm{pH}$ (7). The removal efficiency of pollutants decreased when the $\mathrm{pH}$ was higher than 7. This drop was due to the $\mathrm{OH}$ - ions concentration, that was high so enough to compete with organic molecules from the produced water for adsorption process. Also, when the value of $\mathrm{pH}$ was high the charge of the coagulants types would be less positive and as a result would become less attractive to the anionic organic compounds. 


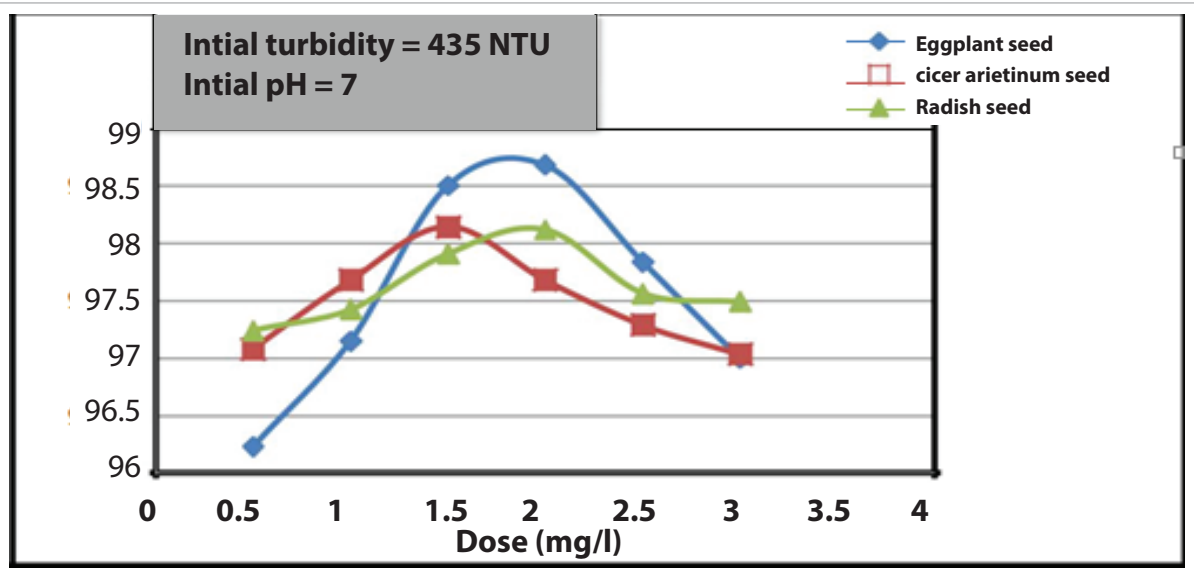

Figure 1: Effect of natural coagulants dose on turbidity removal.

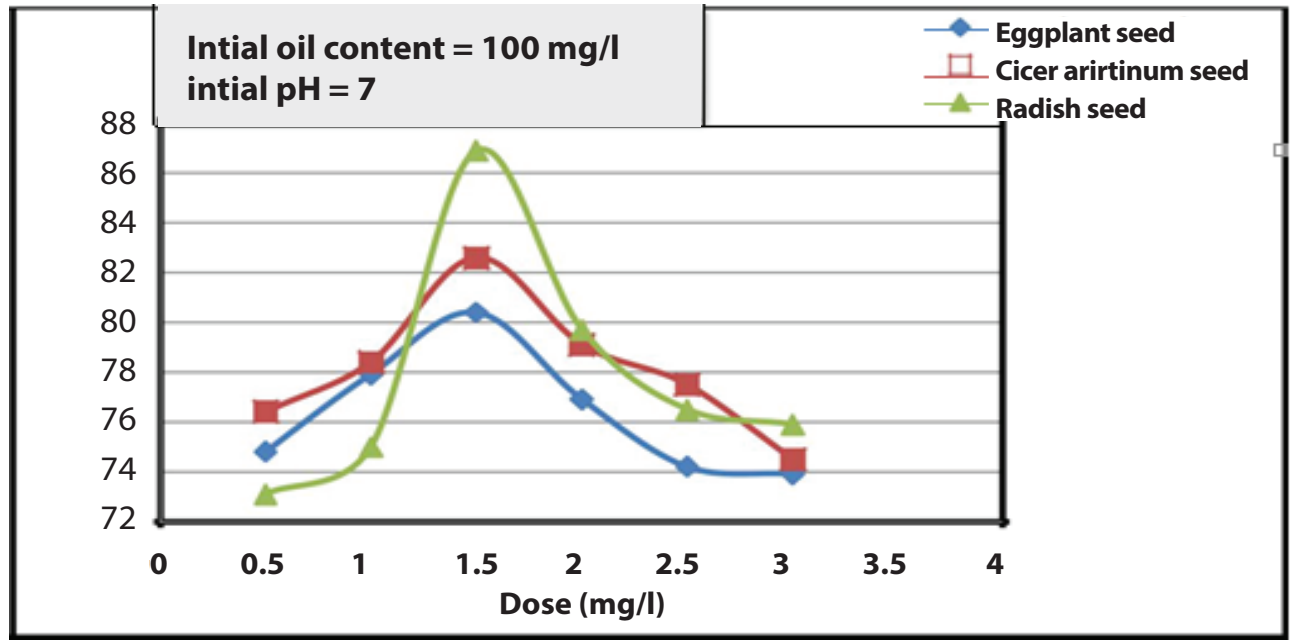

Figure 2: Effect of natural coagulants dose on oil removal.

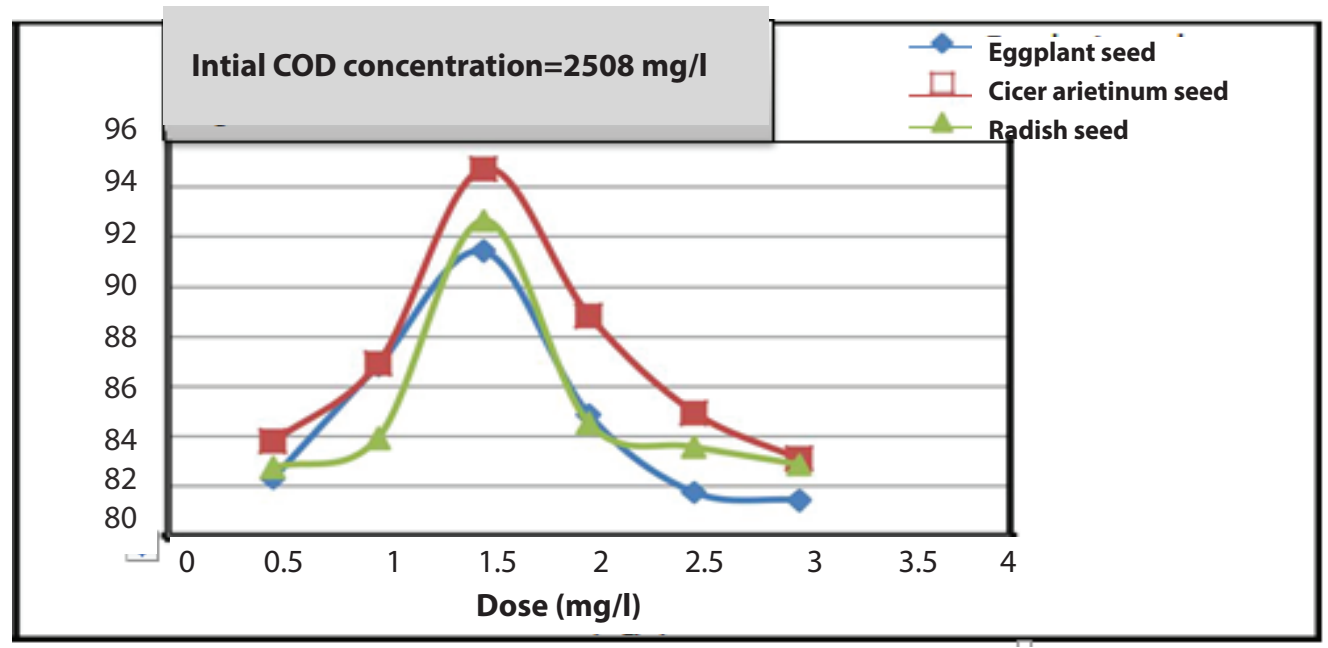

Figure 3: Effect of natural coagulants dose on COD removal. 


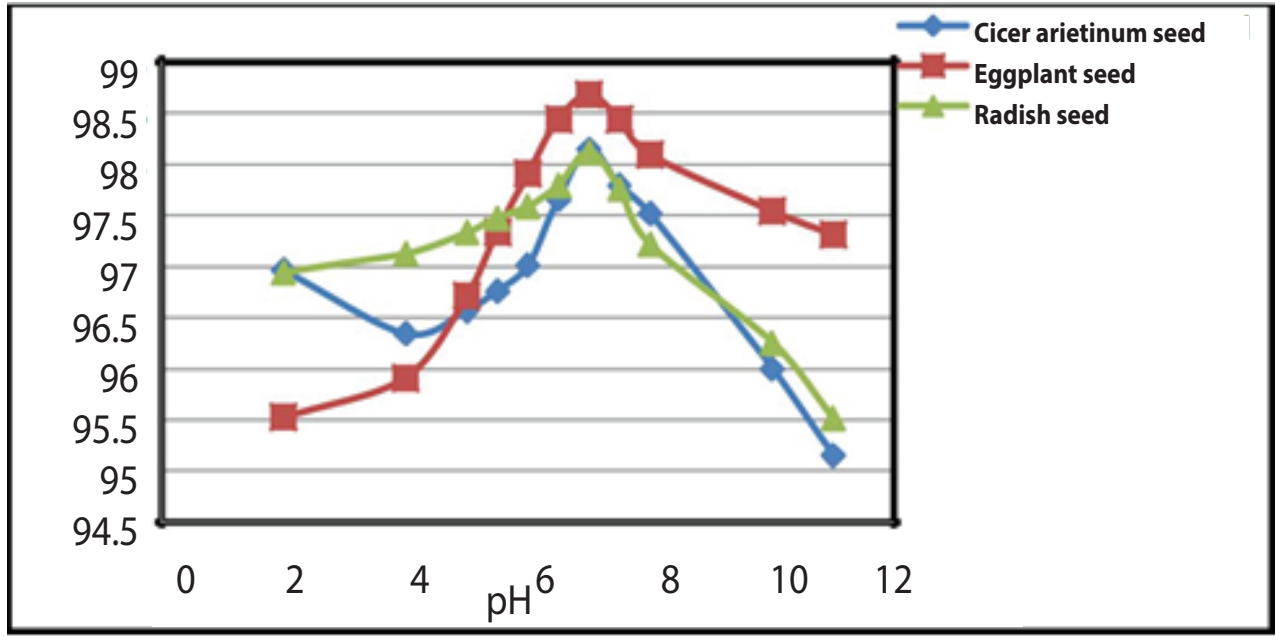

Figure 4: Effect of $\mathrm{pH}$ on turbidity removal.

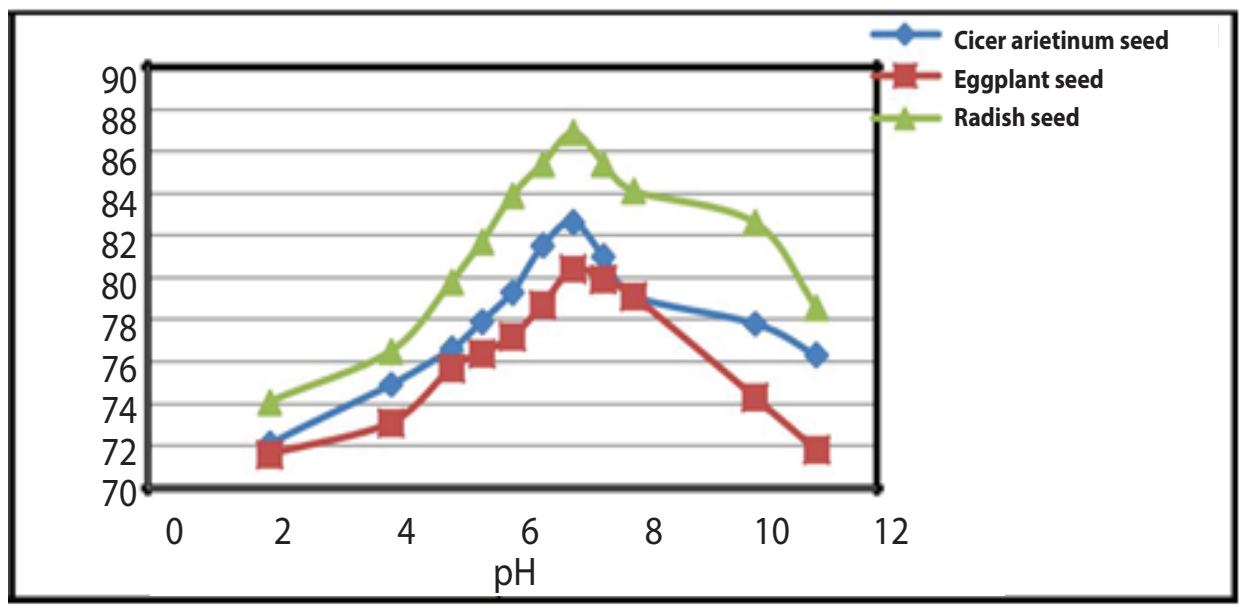

Figure 5: Effect of $\mathrm{pH}$ on oil removal.

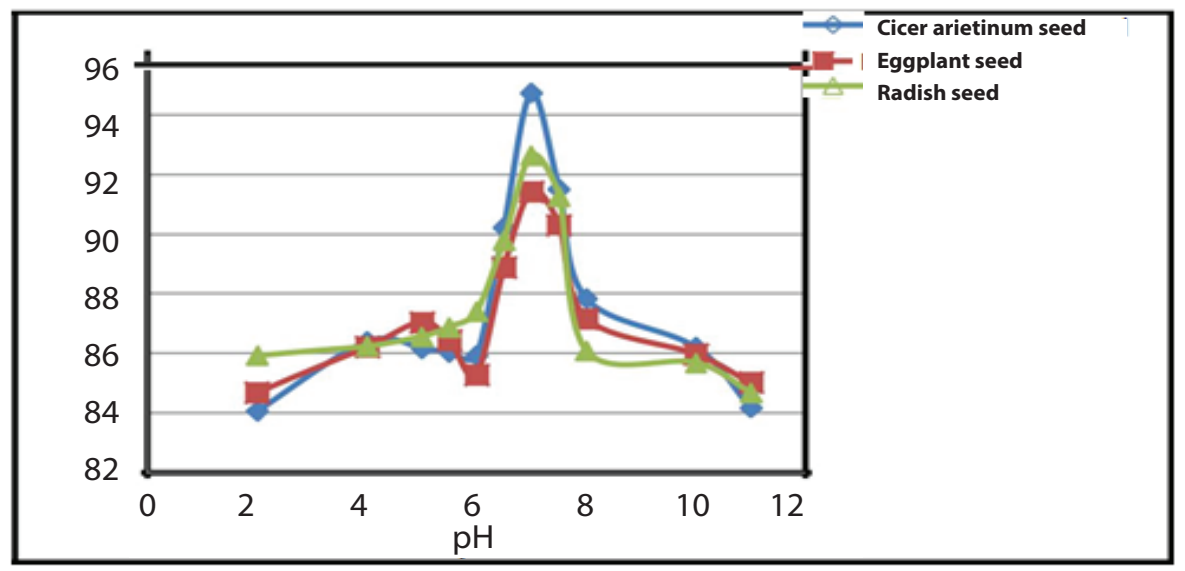

Figure 6: Effect of $\mathrm{pH}$ on COD removal. 


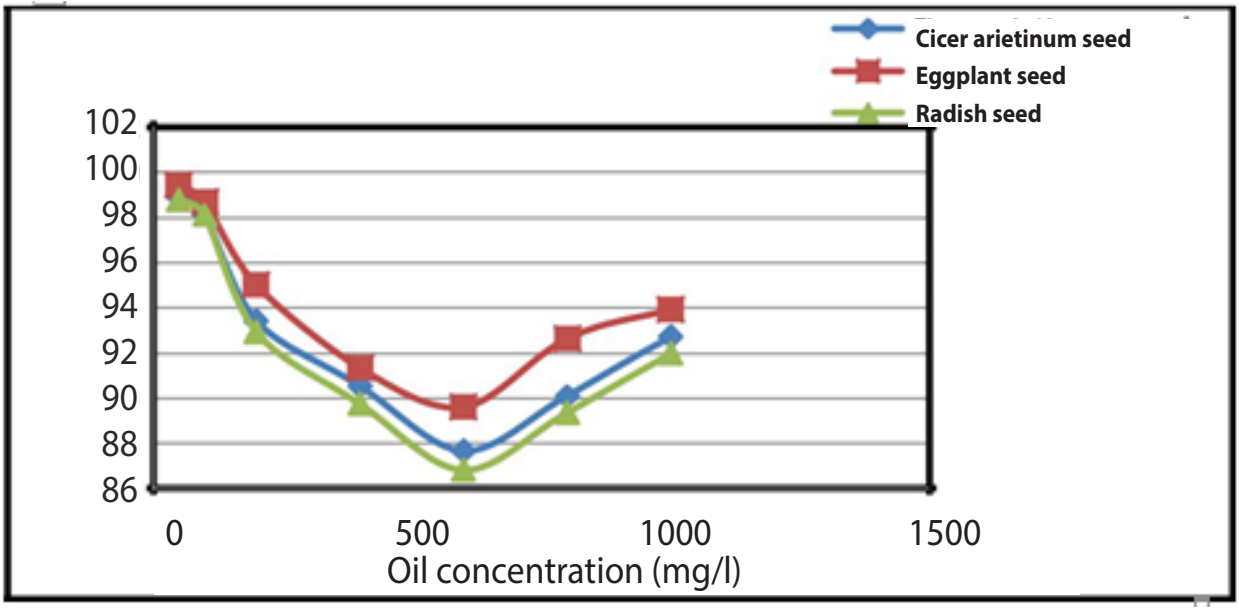

Figure 7: Effect of oil concentration on turbidity removal.

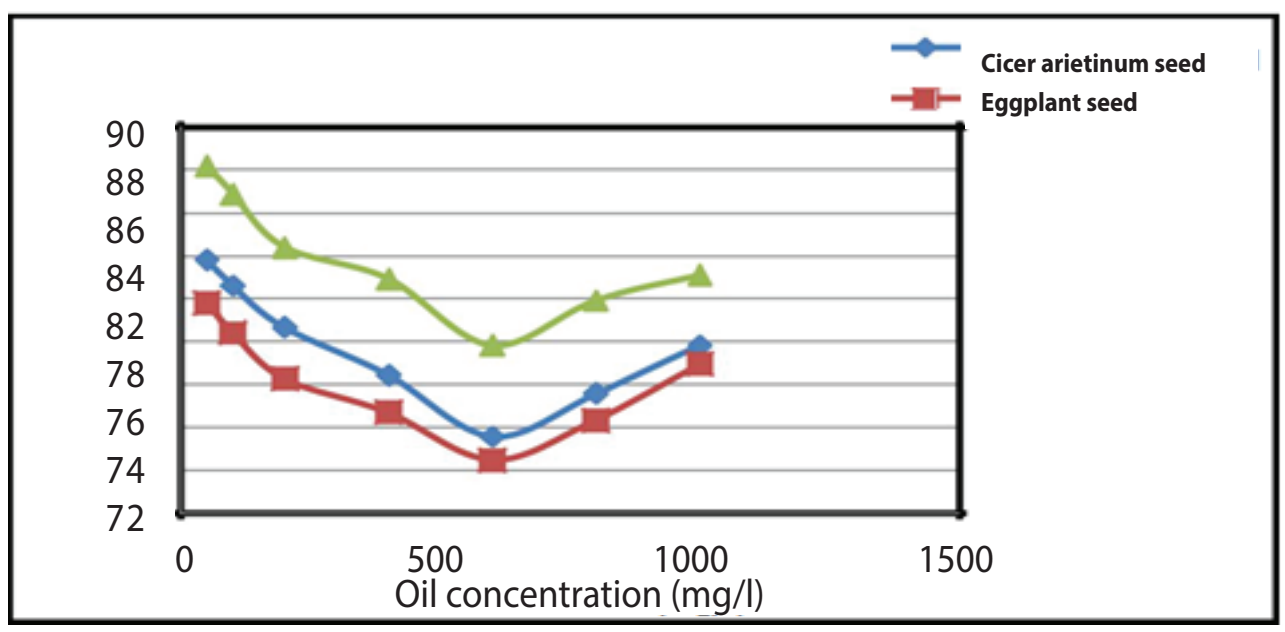

Figure 8: Effect of oil concentration on oil removal.

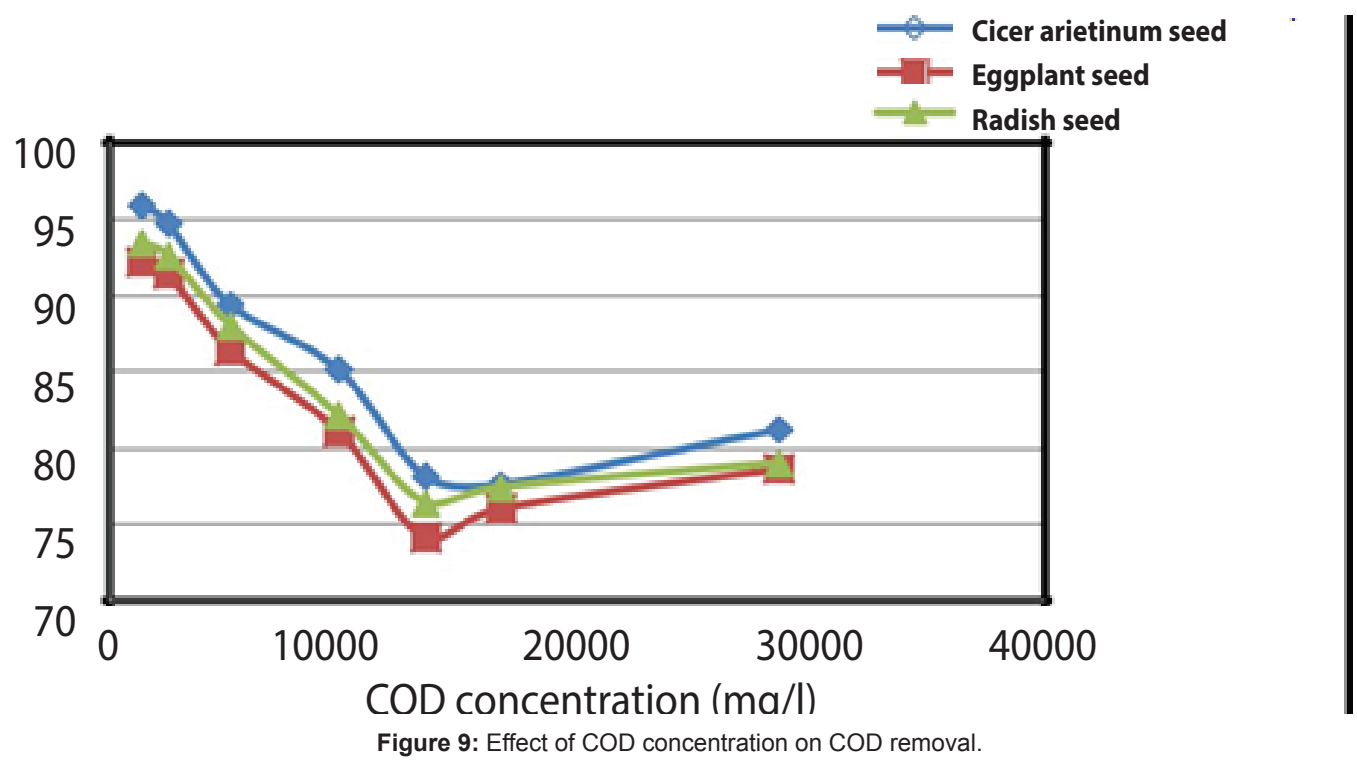




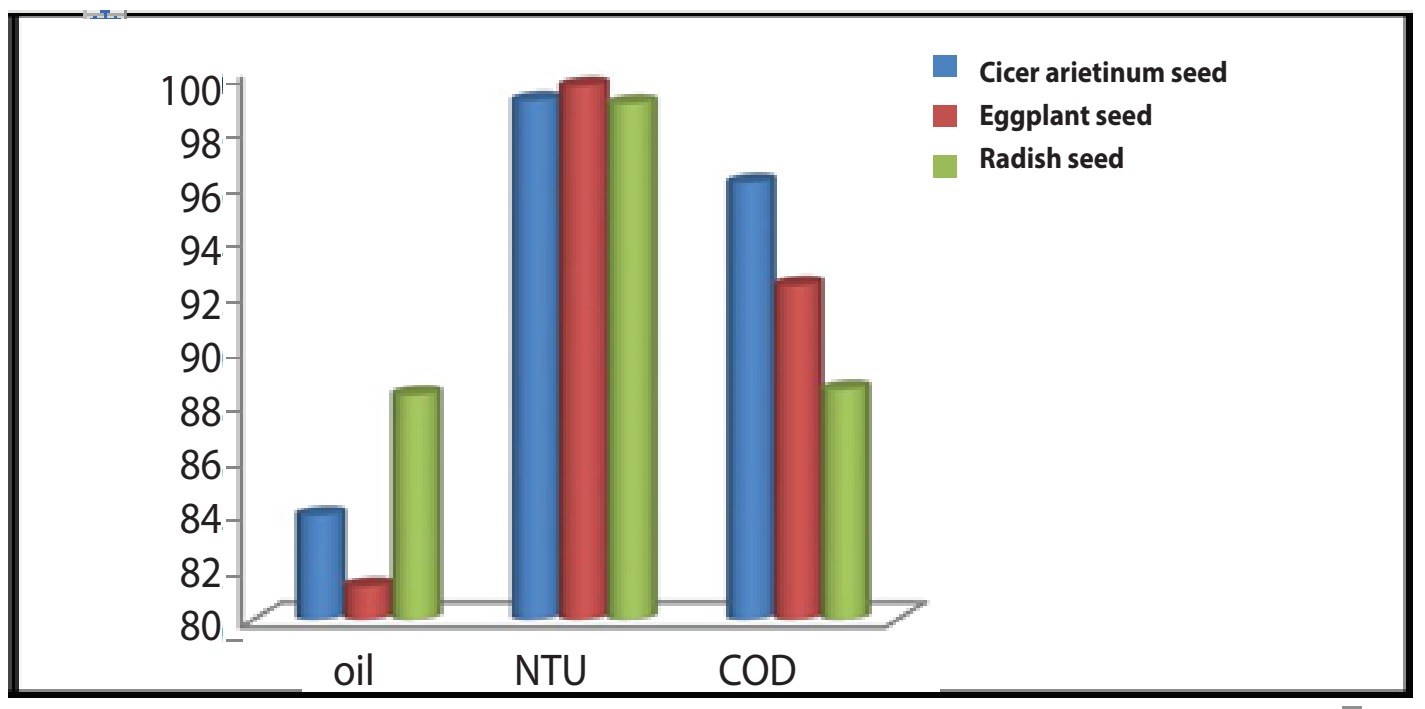

Figure 10: The optimum results obtained from treatment of the produced water sample by using different natural coagulants.

\begin{tabular}{|c|c|}
\hline Parameters & Range \\
\hline COD $(\mathrm{mg} / \mathrm{L})$ & $1357-28609$ \\
\hline TDS $(\mathrm{mg} / \mathrm{L})$ & 100000 \\
\hline Oil \& grease $(\mathrm{mg} / \mathrm{L})$ & $50-10000$ \\
\hline Turbidity (NTU) & 435 \\
\hline $\mathrm{pH}$ & $2-11$ \\
\hline Abbreviations: COD: Chemical Oxygen Demand; TDS: Total Dissolved Solids.
\end{tabular}

Table 1: Qualitative characteristics of synthetically produced water.

\section{Determination of optimum oil concentration}

The results are shown in Figures 7, 8 and 9. Different oil concentrations (50-1000) $\mathrm{mg} / \mathrm{L}$ and COD $(1357$ - 26809) $\mathrm{mg} / \mathrm{L}$ were used. These figures show that the removal efficiency for turbidity, Oil and $\mathrm{COD}$ is decreased by increasing the oil concentration from 50 to $600 \mathrm{mg} / \mathrm{L}$ and COD concentration from 1357-13514 mg/L. However, an increase in the removal efficiency of pollutants was noted when the concentration of oil and COD was more than $600 \mathrm{mg} / \mathrm{L}$ and 13514 $\mathrm{mg} / \mathrm{L}$. This increase in the removal efficiency of pollutants caused by the flotation drops of oil to the surface of produced water, resulting in higher oil concentration. It is found from Figure 7 that the higher removal of turbidity $\mathrm{R}=(99.42 \%)(2.49 \mathrm{NTU})$ when add $2 \mathrm{mg} / \mathrm{L}$ of the eggplant seed, while the Figure 8 explains the result of removal efficiency of oil, the optimum oil is $50 \mathrm{ppm}$ when using radish seed that gives $(\mathrm{R} \%=88.2)$, (residual $=5.9 \mathrm{mg} / \mathrm{L})$. It can be seen from Figure 9 that the best COD reduction is $65.1 \mathrm{ppm}$ at $\mathrm{COD}$ concentration $=1357 \mathrm{ppm}$ by using cicer areitiem seed as a coagulant at the optimum parameter.

\section{Comparison of natural coagulants at the optimum conditions}

The optimum results obtained at the optimum natural coagulants dosage $1.5 \mathrm{mg} / \mathrm{L}, \mathrm{pH} 7$, COD concentration $1357 \mathrm{mg} / \mathrm{L}$ and oil concentration $50 \mathrm{mg} / \mathrm{L}$ by using all types of coagulants for oil removal and COD but $1.5 \mathrm{mg} / \mathrm{L}$ by using Cicer arietinum seed and $2 \mathrm{mg} / \mathrm{L}$ by using eggplant and radish seed for turbidity removal are shown in Figure 10 below. These results manifest that the Cicer arietinum seed is the best coagulant for reduction of COD, while radish seed gives the best removal of oil content in produced water and the maximum removal of turbidity was by using eggplant seed but the removal of turbidity when using Cicer arietinum seed and radish seed is approximately similar.

\section{Conclusion}

In this work, the application of the coagulation/ flocculation process oil field produced water was studied by using different types of natural coagulant, and it was proved to be an efficient and promising method. The natural coagulant of eggplant seed, when used as a coagulant, seems to be more effective than Cicer arietinum seed and radish seed for reduction of turbidity while the radish seed is more effecive than eggplant seed and Cicer arietinum seed for reduction of oil content from wastewater. Cicer arietinum is more efficient in reducing of COD when compared with the other two coagulants that used; this is depending on the presence of protein in the natural coagulant. The highest removal of oil, COD and turbidity were $99.42 \%, 88.2 \%$ and $95.91 \%$ with Eggplant plant, Radish and Cicer arietinum seed, respectively. The natural coagulant as a coagulant instead of commercial alum can be suggested to be used for the sedimentation process because of its efficiency, availability of sources, low cost and biodegradability, producing less amount of sludge and no change occurs in the value of water $\mathrm{pH}$ during the process treatment.

\section{Acknowledgments}

The authors would like to thank the staff of petroleum research and development centre in Oil Ministry of Iraq for their support during conducting this work.

\section{References}

1. McCormack P, Jones P, Hetheridge MJ, Rowland SJ (2001) Analysis of oilfield produced waters and production chemicals by electrospray ionisation multistage mass spectrometry (ESI-MSn). Wat Res 35: 3567-3578.

2. Fakhrul-Razi A, Pendashteh A, Abdullah LC, Biak DRA, Madaeni SS, et al (2009) Review of technologies for oil and gas produced water treatment. J Hazard Mater 170: 530-551.

3. Radoiu MT, Martin DI, Calinescu I, lovu H (2004) Preparation of polyelectrolytes for wastewater treatment. J Hazard Mater 106: 27-37.

4. Oladoja NA (2015) Headway on natural polymeric coagulants in water and wastewater treatment operations. J Wat Proc Eng 6: 174-192.

5. Yue QY, Gao BY, Wang Y, Zhang H, Sun X, et al. (2008) Synthesis of polyamine flocculants and their potential use in treating dye wastewater. J Hazard Mater 152: $221-227$

6. Wong SS, Teng TT, Ahmad AL, Zuhairi A, Najafpour G (2006) Treatment of pulp and paper mill wastewater by polyacrylamide (PAM) in polymer induced flocculation. J Hazard Mater 135: 378-388. 
Citation: Khader EH, Mohammed THJ, Mirghaffari N (2018) Use of Natural Coagulants for Removal of COD, Oil and Turbidity from Produced Waters in the Petroleum Industry. J Pet Environ Biotechnol 9: 374. doi: 10.4172/2157-7463.1000374

Page 7 of 7

7. Ahmad AL, Ismail S, Bhatia S (2005) Optimization of coagulation-flocculation process for palm oil mill effluent using response surface methodology. Environ Sci Technol 39: 2828-2834.

8. Tatsi AA, Zouboulis AI, Matis KA, Samaras P (2003) Coagulation-flocculation pretreatment of sanitary landfill leachates. Chemosphere 53: 737-744.

9. Yin CY (2010) Emerging usage of plant-based coagulants for water and wastewater treatment. Process Biochemistry 45: 1437-1444.

10. Jiang JG (2007) Development of coagulation theory and pre- polymerized coagulants for water treatment. Sep Purif Rev 30: 127-141.

11. Jiang JQ, Graham NJ D (1998) Pre-polymerised inorganic coagulants and phosphorus removal by coagulation-A review. Water SA 24: 237-244.

12. Duan JM, Gregory J (2002) Coagulation by hydrolysing metal salts. Adv Colloid Interface Sci 100: 475-502.

13. Letterman RD (1999) Water quality and treatment. A Handbook of Community Water Supplies ( $5^{\text {th }}$ edn) McGraw-Hill Inc, New York, USA.

14. Exall KN, Vanloon GW (2000) Using coagulants to remove organic matter. J AWWA 92: 93-102.
15. Saravanan J, Priyadharshini D, Soundammal A, Sudha G, Suriyakala K (2017) Wastewater Treatment using Natural Coagulants. Int J Civ Eng 4: 40-42.

16. Jeon JR, Kim EJ, Kim YM, Murugesan K, Kim JH, et al. (2009) Use of grape seed and its natural polyphenol extracts as a natural organic coagulant for removal of water turbidity by natural coagulants obtained from chestnut and acorn. Bioresource Technology 100: 6639-6643.

17. Antov MG, Sciban MB, Pentrovic NJ (2010) Proteins from common bean (Phaseolus vulgaris) seed as a natural coagulant for potential application in water turbidity removal. Bioresource Technol 101: 2167-2172.

18. Moussas PA, Zouboulis Al (2009) A new inorganic-organic composite coagulant, consisting of Polyferric Sulphate (PFS) and Polyacrylamide (PAA). Wat Res 43: 3511-3524.

19. Asrafuzzaman M, Fakhruddin ANM, Hossain A (2011) Reduction of turbidity of water 13 using locally available natural coagulants. ISRN Microbiology 20: 1-6.

20. Harush DP, Hampannavar U, Mallikarjunaswami ME (2011) Treatment of dairy wastewater using aerobic biodegradation and coagulation. Int J Environ Sci Res 1: 2-26. 